\section{Crop Coefficient-based Deficit Irrigation and Planting Density for Onion: Growth, Yield, and Bulb Quality}

\author{
Daniel I. Leskovar ${ }^{1,2}$ and Shinsuke Agehara \\ Texas AgriLife Research, Vegetable and Fruit Improvement Center, Department \\ of Horticultural Sciences, Texas A\&M University, 1619 Garner Field Road, \\ Uvalde, TX 78801 \\ Kilsun Yoo \\ Vegetable and Fruit Improvement Center, Department of Horticultural \\ Sciences, Texas A\&M University, College Station, TX 77843
}

\section{Nuria Pascual-Seva \\ Departamento de Producción Vegetal, Universitat Politècnica de València, 46022, Spain}

Additional index words. Allium Cepa, evapotranspiration, bulb size, pungency, flavonoids, quercetin

\begin{abstract}
Agricultural communities in the semiarid regions of the world are constantly being affected by water scarcity, increased regulations restricting water use, strong competition for irrigation water with the urban sector, and severe drought periods. Conversely, the consumer demand for high-quality and nutritious foods is increasing rapidly. A 2-year field study evaluated growth, yield, and bulb quality in response to precision planting density and deficit irrigation of onion (Allium cepa L.) in southwest Texas. Seeds of short-day sweet onion cv. Texas Grano $1015 \mathrm{Y}$ were planted in the field on 11 Nov. 2007 and 30 Oct. 2008 at two planting densities (PDs), 397,000 (standard) and 484,000 (high) seeds/ha. Three irrigation rates using growth stage-specific crop coefficients and subsurface drip were imposed after plants were fully established, $100 \%$, $\mathbf{7 5 \%}$, and $50 \%$ crop evapotranspiration rates (ETc). Total rainfall plus irrigation received for each irrigation rate were 594, 501, and $413 \mathrm{~mm}$ in 2008 and 662, 574, and $486 \mathrm{~mm}$ in 2009. In both seasons, there were consistent trends in growth, yield, and quality parameters. Leaf fresh weight was unaffected by PD but was reduced by deficit irrigation at 50\% ETc. Although increasing planting density reduced the average bulb size by $12 \%$, it increased the number of marketable bulbs by $21 \%$ to $33 \%$ and marketable yield by $7 \%$ to $14 \%$. In contrast, deficit irrigation showed a trend to reduce both the number of bulbs and bulb size with yield reductions of $8 \%$ to $13 \%$ at $75 \%$ ETc and $19 \%$ to $27 \%$ at $50 \%$ ETc. Neither planting density nor deficit irrigation rate had a significant effect on soluble solids content, pungency, or quercetin contents. These results suggest that growers of short-day onions in semiarid regions could adjust PDs to target high-value bulb sizes. Implementing water-conserving practices (deficit irrigation at $75 \%$ ETc rate) would result in a decrease of high-value bulb grades and modest losses in yield but not flavor or nutritional components.
\end{abstract}

\footnotetext{
Received for publication 27 June 2011. Accepted for publication 1 Nov. 2011.

This material is based on work supported by the National Institute of Food and Agriculture, U.S. Department of Agriculture under Agreement No. 2008-34402-19195, "Designing Foods for Health," through the Vegetable and Fruit Improvement Center, Texas AgriLife Research and Agreement No. 2008-34461-19061, "Rio Grande Basin Initiative." We thank Juan Gonzalez, Juan Esquivel, Basilio Quiroga, and Melina Gonzales for their assistance in field procedures and Seminis, Netafim, and Ag Equipment for providing seed and irrigation materials. ${ }^{1}$ Professor.

${ }^{2}$ To whom reprint requests should be addressed; e-maild-leskovar@tamu.edu.
}

Edible alliums are important crops worldwide. Approximately $46 \%$ of the international trade value in alliums is for dry bulb onions (Brewster, 2008). World dry bulb onion production in 2009 was 72 million $t$ cultivated on 202,446 ha (FAO, 2010). The major producing countries in 2008 were China, India, and the United States with 21, 14, and 3 million t, respectively (FAO, 2010). Bulb onions are produced from the subarctic regions to the humid tropics, although they are best adapted to production in subtropical and temperate areas (Brewster, 2008).

Improvements in water use efficiency in agriculture are needed as a result of scarcity of fresh water, increasing costs, and increasing world population growth (Bessembinder et al., 2005). Agriculture uses $70 \%$ of the developed water supplies in the United States (FAO, 2010); therefore, water conservation programs are expected to play a pivotal role to improve water use efficiency. Significant water savings can be achieved by deliberately stressing plants to a certain profitable level. This management technique is generally known as deficit irrigation. If irrigation rates are reduced at predetermined developmental stages where deficits would not severely impact productivity, it is called regulated deficit irrigation, which was first proposed by Chalmers et al. (1981) for peach [Prunus persica (L.) Batsch] trees. Because of increasing water scarcity, it is expected that deficit irrigation would be adopted for a wide variety of crops and in more regions, especially in arid and semiarid climates of the world (FAO, 2002). Furthermore, the application of growth stagespecific crop coefficients $\left(\mathrm{K}_{\mathrm{C}}\right)$ for irrigation management in onion can provide precise water applications to meet crop water demand, resulting in greater yields, crop quality, and enhanced water use efficiency (Piccinni et al., 2009).

Subsurface drip irrigation allows the application of small amounts of water to the soil through drippers placed directly in the root zone, thereby improving irrigation water use efficiency, nitrogen use efficiency, and profitability (Halvorson et al., 2008; Shock et al., 2007). Patel and Rajput (2008, 2009) reported higher yields in onion cultivated with subsurface drip when compared with surface drip irrigation. High irrigation efficiencies in onions can also be achieved with a center pivot using drops converted to low-energy precision application heads placed at $\approx 0.3 \mathrm{~m}$ above the ground (Piccinni et al., 2009).

It is questionable whether conventional plant spacing results in maximum yield, particularly for root and tuber crops. In accordance with Caliskan et al. (2009), the optimization of plant density is of great importance in maximizing yield, because increasing plant density per unit area normally results in competition between plants for growth resources such as solar radiation, water, and nutrients, whereas suboptimal densities lead to waste of these inputs.

Onions are primarily consumed for their flavor and ability to enhance the flavor of other foods (Kopsell and Randle, 1997). Flavor intensity in onion is dominated by organosulphur compounds arising from the enzymatic decomposition of S-alk(en)yl-L-cysteine S-oxide when the cells are mechanically ruptured. This reaction produces thiopropanol S-oxide, pyruvic acid, ammonia, and many sulfur volatiles (Whitaker, 1976). The determination of pyruvate as an indicator of pungency is the most commonly established method for pungency assessment in onion. Pungency level and total soluble solids are important quality attributes of onion bulbs for processing and storage. Pungency contributes to postharvest life and processing quality (Dhumal et al., 2007), and it is an indicator of the onion flavor intensity (Abayomi et al., 2006).

Onion has significant nutritional and medicinal properties such as anticarcinogenic, 
antiplatelet activity, antithrombotic activity, and antiasthmatic and antibiotic effects (Griffiths et al., 2002). They are good sources of polyphenolic flavonoids such as quercetin (aglycone and its glycosides), which comprise a large group of natural antioxidants (Caridi et al., 2007; Mogren et al., 2007). The content of these phytonutrients in onions is highly dependent on genetic (genotype, cultivar, etc.) as well as environmental factors. For instance, yellow, red, and pink onions have been shown to contain higher quercetin concentrations, up to $286 \mu \mathrm{g} \cdot \mathrm{g}^{-1}$ fresh weight, than white onions (Patil et al., 1995). The effect of irrigation strategies on quercetin content of onion remains largely unknown.

Previous investigations have not evaluated the interactive effects of PD and deficit irrigation rates using specific growth-stage crop coefficients as a tool for evapotranspirationbased irrigation management of short-day onions. Selecting improved irrigation practices for onions is crucial for production in water-limited areas of the world. The aim of this 2-year study was to determine the optimal combination of PD and subsurface drip

Table 1. Chemical properties of soils at planting.

\begin{tabular}{lcc}
\hline & \multicolumn{2}{c}{ Season } \\
\cline { 2 - 3 } Property & 2008 & 2009 \\
\hline $\mathrm{pH}$ & 8.00 & 7.97 \\
$\mathrm{EC}\left(\mathrm{dS} \cdot \mathrm{m}^{-1}\right)$ & 0.42 & 0.37 \\
Organic matter $(\%)$ & 2.26 & 2.52 \\
Total C $\left(\mathrm{g} \cdot \mathrm{kg}^{-1}\right)$ & 37.9 & 38.5 \\
Total N $\left(\mathrm{g} \cdot \mathrm{kg}^{-1}\right)$ & 1.00 & 0.89 \\
$\mathrm{NH}_{4}^{+}-\mathrm{N}\left(\mathrm{mg} \cdot \mathrm{kg}^{-1}\right)$ & 13.6 & 13.7 \\
$\mathrm{NO}_{3}-\mathrm{N}\left(\mathrm{mg} \cdot \mathrm{kg}^{-1}\right)$ & 5.1 & 5.1 \\
$\mathrm{P}\left(\mathrm{mg} \cdot \mathrm{kg}^{-1}\right)$ & 57 & 48 \\
$\mathrm{~K}\left(\mathrm{mg} \cdot \mathrm{kg}^{-1}\right)$ & 870 & 810 \\
$\mathrm{Ca}\left(\mathrm{mg} \cdot \mathrm{kg}^{-1}\right)$ & 19,457 & 16,479 \\
$\mathrm{Mg}\left(\mathrm{mg} \cdot \mathrm{kg}^{-1}\right)$ & 370 & 341 \\
$\mathrm{~S}\left(\mathrm{mg} \cdot \mathrm{kg}^{-1}\right)$ & 39 & 26 \\
$\mathrm{Na}\left(\mathrm{mg} \cdot \mathrm{kg}^{-1}\right)$ & 179 & 133 \\
$\mathrm{Fe}\left(\mathrm{mg} \cdot \mathrm{kg}^{-1}\right)$ & 8.1 & 7.1 \\
$\mathrm{Zn}\left(\mathrm{mg} \cdot \mathrm{kg}^{-1}\right)$ & 1.9 & 0.6 \\
$\mathrm{Mn}\left(\mathrm{mg} \cdot \mathrm{kg}^{-1}\right)$ & 11.1 & 15.2 \\
$\mathrm{Cu}\left(\mathrm{mg} \cdot \mathrm{kg}^{-1}\right)$ & 0.8 & 0.9 \\
\hline $\mathrm{EC}$
\end{tabular}

$\mathrm{EC}=$ electrical conductivity; $\mathrm{C}=$ carbon; $\mathrm{N}=$ nitrogen; $\mathrm{P}=$ phosphorus; $\mathrm{K}=$ potassium; $\mathrm{Ca}=$ calcium; $\mathrm{Mg}=$ magnesium $; \mathrm{S}=$ sulfur; $\mathrm{Na}=$ sodium; $\mathrm{Fe}=$ iron; $\mathrm{Zn}=$ zinc; $\mathrm{Mn}=$ manganese; $\mathrm{Cu}=$ copper.

Table 2. Dates and days after planting (DAP) corresponding to the growth stage-specific crop coefficient $(\mathrm{Kc})$.

\begin{tabular}{|c|c|c|c|c|c|}
\hline & \multirow[b]{2}{*}{$\mathrm{Kc}$} & \multicolumn{2}{|c|}{2008 season } & \multicolumn{2}{|c|}{2009 season } \\
\hline & & Date & DAP & Date & DAP \\
\hline Planting & 0.50 & 11 Nov. & 0 & 30 Oct. & 0 \\
\hline $\begin{array}{l}\text { Initial } \\
\quad \text { irrigation }\end{array}$ & 0.50 & 15 Nov. & 3 & 1 Nov. & 2 \\
\hline 2 true leaves & 0.60 & 7 Dec. & 25 & $1 \mathrm{Dec}$. & 32 \\
\hline 3-4 true leaves & 0.70 & 28 Dec. & 46 & 29 Dec. & 60 \\
\hline $\begin{array}{l}\text { Beginning of } \\
\text { bulbing }\end{array}$ & 0.80 & 29 Feb. & 109 & 9 Feb. & 102 \\
\hline $\begin{array}{l}\text { Bulb } \\
\text { development }\end{array}$ & 0.85 & 11 Apr. & 151 & 2 Mar. & 123 \\
\hline $\begin{array}{l}\text { Bulb fully } \\
\text { developed }\end{array}$ & 0.90 & 11 May & 181 & 27 Apr. & 179 \\
\hline Dry leaf stage & 0.70 & 20 May & 190 & 11 May & 193 \\
\hline Harvest & 0.70 & 27 May & 197 & 18 May & 200 \\
\hline
\end{tabular}

irrigation level that would lead to water savings while maintaining yield and quality of short-day onion.

\section{Materials and Methods}

Cultural practices. Experiments were carried out in two seasons, 2008 and 2009, at the Texas AgriLife Research Center, Uvalde, TX (lat. $29^{\circ} 1^{\prime} \mathrm{N}$, long. $99^{\circ} 5^{\prime} \mathrm{W}$, elevation $283 \mathrm{~m}$ ). The soil was silty clay (fine-silty, mixed, hyperthermic Aridic Calciustolls) with an available soil moisture-holding capacity of $17 \%$. Pre-plant soil chemical properties are shown in Table 1. The experiment used the short-day onion cultivar Texas Grano 1015Y. Dates for planting, phenological stages, and harvesting are shown in Table 2. Subsurface drip irrigation was installed in the center of each bed at $10-\mathrm{cm}$ depth (Netafim, $1.09 \mathrm{~L} \cdot \mathrm{h}^{-1}$ with drippers spaced $40.6 \mathrm{~cm}$ in 2008 and Netafim, $1.14 \mathrm{~L} \cdot \mathrm{h}^{-1}$ with drippers spaced $30.4 \mathrm{~cm}$ in 2009). Total fertilizers applied as fertigation were $135 \mathrm{~N}-26 \mathrm{P}-81 \mathrm{~K} \mathrm{~kg} \cdot \mathrm{ha}^{-1}$ in the 2008 season and $135 \mathrm{~N}-42 \mathrm{P}-47 \mathrm{~K} \mathrm{~kg} \cdot \mathrm{ha}^{-1}$ in the 2009 season. The amount of water applied for each irrigation event was recorded with totalizing water flow meters connected to the irrigation system. Volumetric water content changes of the soil were monitored continuously with $\mathrm{ECH}_{2} \mathrm{O}$ soil moisture probes (EC-5; Decagon Devices Inc., Pullman, WA) installed in the middle of the beds at 15-, 30-, and 45-cm depth. Sensors were placed at $100 \%$ ETc in 2008 and for all treatments in the 2009 season.

The study was conducted using a factorial experiment. PDs used were 397,428 (standard PD) and 484,365 (high PD) seeds/ha resulting from seeds planted at 10 and $8 \mathrm{~cm}$ apart in the same row, respectively. The irrigation rates were $100 \%, 75 \%$, and $50 \%$ ETc. The irrigation scheduling was based on the daily crop ETc of the well-watered crop, which was calculated as the product of the daily reference evapotranspiration and the related onion $\mathrm{Kc}$. The ETc values were estimated using weather data from a local weather station and the Penman-Monteith method and adjusted by stage-specific crop coefficients (Table 2) developed for onions at the Texas AgriLife Research Center in Uvalde and as described in Piccinni et al. (2009). Irrigation for the $100 \%$ ETc treatment was triggered when the total cumulative daily ETc reached $\approx 15 \mathrm{~mm}$, and rates for $75 \%$ and $50 \%$ ETc were adjusted accordingly. Seeds were planted on four rows spaced $10 \mathrm{~cm}$ apart in the bed. To ensure adequate stand establishment, plants for all treatments were first irrigated with $100 \%$ $\mathrm{ETc}$, and the differential irrigation treatments started after plants were fully established. Data on total rainfall and initial and differential irrigation for both seasons are shown in Table 3.

Plant measurements. Plants were sampled periodically throughout development at various dates after planting (DAP). The following growth variables were measured: leaf number per plant, plant height, leaf chlorophyll index in the first fully developed leaf with a SPAD-502 m (Konica Minolta Sensing Inc., Tokyo, Japan), stem and bulb diameter, and leaf and bulb fresh weight (FW). Bulbing ratio (bulb diameter/stem diameter) was calculated at three stages of development in both seasons.

Yield and bulb sizes. Harvests were done on 6-m long plots on 27 May 2008 and 18 May 2009 , a time when more than $80 \%$ of the leaves (pseudostems) were bent over. At harvest bulbs were sorted by diameter into different commercial classes: small (less than $5.7 \mathrm{~cm})$, medium $(5.7-7.6 \mathrm{~cm})$, large $(7.6$ 9.5), jumbo (9.5-10.5), and colossal (greater than $10.5 \mathrm{~cm}$ ). Bulb number, marketable yield $\left(\mathrm{t} \cdot \mathrm{ha}^{-1}\right)$, percentage of marketable to total yield, and average bulb size ( $\mathrm{g} / \mathrm{bulb}$ ) were determined. During bulb sorting, 10 large bulbs per replication were sampled for bulb quality determination. Total soluble solids ( ${ }^{\circ}$ Brix) were measured with a digital refractometer from the onion juice squeezed by a garlic press. Pungency as determined by the pyruvic acid concentration and the flavonoid quercetin was measured as described subsequently.

Pyruvic acid analysis. All onion bulbs were tested within 1 month after harvest. The whole onion bulb was blended in a home mixer after the neck, basal plate, and skins were removed. The onion tissues were blended without adding water and the juice was collected by filtering the puree through a filter paper. Thereafter, the juice was kept in plastic vials and frozen at $-20{ }^{\circ} \mathrm{C}$ until the time of analysis. The pyruvic acid content in the juice was measured by an automatic system developed by Yoo and Pike (1999). Sodium pyruvate solutions ranging from 0 to 10 $\mu$ moles $\cdot \mathrm{mL}^{-1}$ were used to construct a standard curve.

Table 3. Rainfall and irrigation during 2008 and 2009 seasons.

\begin{tabular}{lcccccc}
\hline Season & $\begin{array}{c}\text { Irrigation } \\
\text { rate }(\% \text { ETc })\end{array}$ & $\begin{array}{c}\text { Rainfall } \\
(\mathrm{mm})\end{array}$ & Initial & Differential $^{\mathrm{z}}$ & Total & $\begin{array}{c}\text { Rainfall and } \\
\text { irrigation }(\mathrm{mm})\end{array}$ \\
\hline 2008 & 100 & 85 & $156(10)^{\mathrm{y}}$ & $353(22)$ & $509(32)$ & 594 \\
& 75 & 85 & $156(10)$ & $260(22)$ & $417(32)$ & 501 \\
& 50 & 85 & $156(10)$ & $172(22)$ & $328(32)$ & 413 \\
2009 & 100 & 98 & $177(13)$ & $387(20)$ & $564(33)$ & 662 \\
& 75 & 98 & $177(13)$ & $299(20)$ & $476(33)$ & 574 \\
& 50 & 98 & $177(13)$ & $211(20)$ & $388(33)$ & 486 \\
\hline
\end{tabular}

${ }^{2}$ Differential irrigation was established on 30 Jan. and 15 Jan. (79 and $77 \mathrm{~d}$ after planting) in 2008 and 2009 seasons, respectively.

${ }^{y}$ Values in parentheses are the number of irrigation events.

$\mathrm{ETc}=$ evapotranspiration 
Quercetin analysis. A cross-section of onion tissue $(20 \mathrm{~g})$ was blended with $80 \mathrm{~mL}$ $80 \%$ ethanol and filtered with a P-1 filter paper (Fisher, Pittsburg, PA). Four milliliters of the extract was mixed with $2 \mathrm{~mL} 3 \mathrm{~N} \mathrm{HCl}$ in a 15-m centrifuge tube and cooked for $60 \mathrm{~min}$ at $90{ }^{\circ} \mathrm{C}$ with a glass tube vent (Lee et al., 1995). The sample was cooled, filtered by a $0.45-\mu \mathrm{m}$ filter, and placed into a highperformance liquid chromatography (HPLC) sample vial $(0.75 \mathrm{~mL})$. The sample was injected into an HPLC system consisting of a Perkin Elmer (Norwalk, CT) LC 200 series pump, an LC 200 autosampler, an ultraviolet/Vis detector, and a Nova-Pak C18 column (3.9 mm $\times$ $15 \mathrm{~cm}$; Waters, Milford, MA). The mobile phase was $45 \% \mathrm{MeOH}$ with $0.5 \%$ phosphoric acid at a flow rate of $0.8 \mathrm{~mL} \cdot \mathrm{min}^{-1}$ and detection was made at $360 \mathrm{~nm}$. An external standard of quercetin was included in the analysis and used to generate calibration equations for calculating bulb quercetin contents.

Statistical analysis. The experiments over the 2008 and 2009 seasons were conducted using a split plot design with six replications; the planting densities were the main plots and irrigation rates the subplots. Main plots were $91 \mathrm{~m}$ long and $6.1 \mathrm{~m}$ wide and subplots were $91 \mathrm{~m}$ long and $2.03 \mathrm{~m}$ wide. To avoid overlapping from irrigation rates, all samples were taken from the inner two lines per each bed. All growth parameters, yield, and quality data were subjected to analysis of variance using SAS (SAS Institute Inc., 1993). Differences among PDs and irrigation rates were determined according to the Tukey's Studentized range test at $P \leq 0.05$.

\section{Results}

Irrigation. The rainfall contribution was similar in both years, $85 \mathrm{~mm}$ in 2008 and 98 $\mathrm{mm}$ in 2009 (Table 3). In the first season, 32 irrigation events were applied, the first 10 applying the same amount $(156 \mathrm{~mm})$ to all three treatments to ensure an adequate stand establishment. After plants were uniformly established, 22 different irrigation events were applied, 353, 260, and $172 \mathrm{~mm}$ for the $100 \%$, $75 \%$, and $50 \%$ ETc irrigation rates, respectively. In the second season, 33 irrigation events were applied, the first 13 applying the same amount $(177 \mathrm{~mm})$ followed by 20 additional applications, 387, 299, and $211 \mathrm{~mm}$ for the $100 \%, 75 \%$, and $50 \%$ ETc rates, respectively. The rainfall contribution to the total water input was $14 \%$ for the $100 \%$ ETc treatment for both seasons.

Soil moisture content. The relative volumetric soil water content for the 2008 season is presented for $100 \% \mathrm{ETc}$ and high PD at 15-, 30-, and 45-cm depth (Fig. 1). A slight decreasing trend in soil moisture over time was observed at 30- and 45-cm depth after 140 DAP, whereas most of the crop water use was evident in the $15-\mathrm{cm}$ depth. Soil water content for the 2009 season is presented for all treatments, except $15-\mathrm{cm}$ depth at $100 \%$ ETc (defective sensor). At 100\% ETc, a slight decreasing trend in soil moisture over time was also observed at 30 - and $45-\mathrm{cm}$ depth after
154 DAP. Stronger soil moisture changes occurred at $15-\mathrm{cm}$ depth for the $75 \% \mathrm{ETc}$ as compared with 50\% ETc after 145 DAP.
Conversely, soil moisture at $45-\mathrm{cm}$ depth appeared to decline more at $50 \%$ than $75 \%$ and $100 \%$ ETc after $\approx 160$ DAP (Fig. 2).

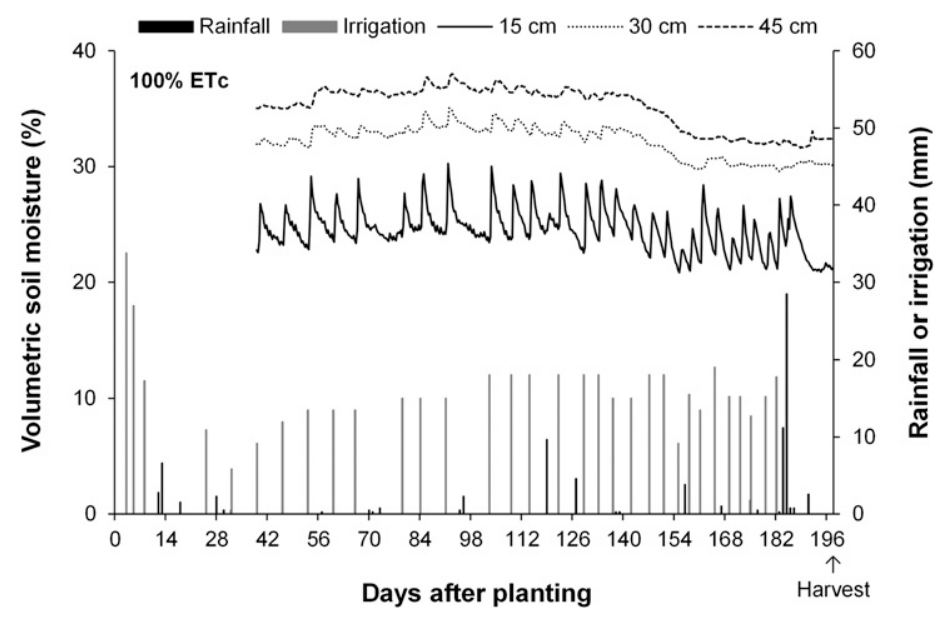

Fig. 1. Soil moisture, rainfall, and irrigation events during the 2008 season.

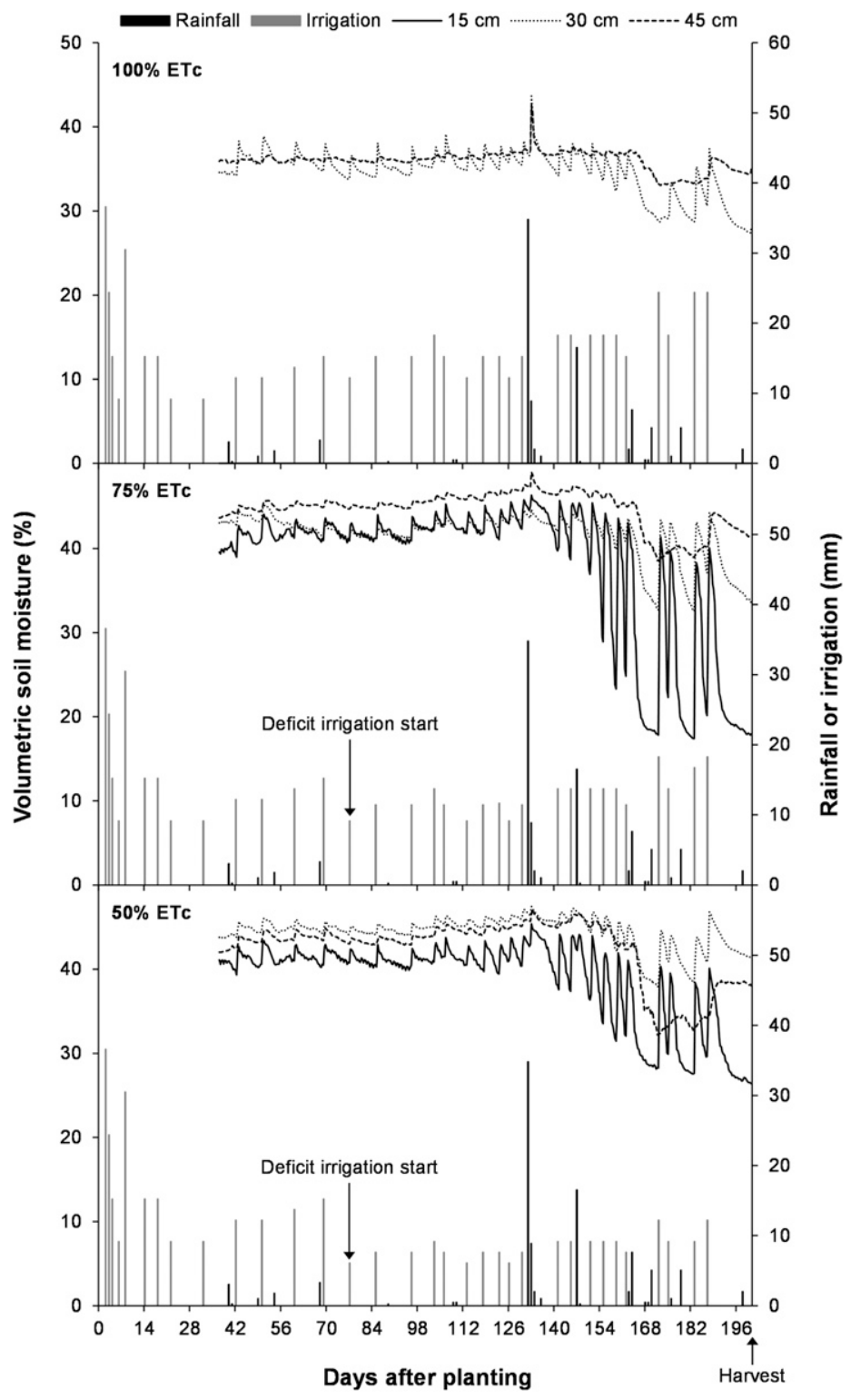

Fig. 2. Soil moisture, rainfall, and irrigation events during the 2009 season. 
Plant growth parameters. Plant growth evaluated as leaf number per plant and plant height were unaffected by PD in both years (not shown). High irrigation rate $(100 \%$ ETc) increased leaf number (up to 11.5 leaves per plant at 161 DAP) in the 2008 season and plant height in both seasons (data not shown).

There was only one significant planting density $\times$ irrigation interaction $(P \leq 0.05)$ for the variables bulbing ratio (Table 4 ), leaf chlorophyll index (Table 5), or leaf and bulb fresh weight (Tables 6 and 7), viz., bulbing ratio at 175 DAP in 2008 (Table 4).

Bulbing ratio was unaffected by $P D$ in both seasons but was affected by irrigation rate in the first season (162 and 175 DAP) increasing with deficit irrigation at 50\% ETc as compared with $100 \%$ ETc. This trend was also observed in the second season, although it was not statistically significant (Table 4). A bulbing ratio of 2 or greater is commonly considered bulb formation. According to these criteria, bulb formation occurred by $\approx 160$ DAP in both seasons.

Leaf chlorophyll index was unaffected by PD $(P \leq 0.05)$ except for a significant reduction in the high PD at 147 DAP in the 2008 season (Table 5). There was a steady increase in leaf chlorophyll index in 2008 at 147 and 161 DAP as irrigation rate decreased from $100 \%$ ETc to $50 \%$ ETc. However, at 175 DAP, the highest leaf chlorophyll index was found with $100 \% \mathrm{ETc}$, suggesting that earlier leaf senescence may have occurred with deficit irrigation in 2008.

Leaf growth per plant (FW basis) was unaffected by planting density but was significantly different in response to irrigation rates in both seasons (Table 6). Overall, leaf growth was highest for $100 \%$, intermediate for $75 \%$, and lowest for $50 \%$ ETc, especially in the last two sampling periods in both 2008 and 2009 seasons.

Bulb FW was significantly lower at high PD at 175 DAP in 2008 but not in the 2009 season. Bulb weight trends in response to irrigation rate were consistent in 2008 and 2009 , but differences were only significant in 2008 . Heavier bulbs were measured at $100 \%$ ETc (271 g) compared with bulbs produced with $75 \%$ and $50 \%$ ETc (244 and $219 \mathrm{~g}$, respectively) at 175 DAP in 2008 (Table 7).

Yield and yield components. Excellent yields were obtained in both seasons (range, 52 to $72 \mathrm{t} \cdot \mathrm{ha}^{-1}$ ). There were no significant planting density $\times$ irrigation rate interactions $(P \leq 0.05)$ for marketable yield and yield components (Table 8). As expected, the number of bulbs was lower at the standard PD compared with high PD. Conversely, the average bulb weight was higher for the standard PD, 276 and $232 \mathrm{~g}$, as compared with the high PD, 244 and $201 \mathrm{~g}$, for the 2008 and 2009 seasons, respectively. Bulb weight also decreased with deficit irrigation $(50 \%$ and $75 \%$ ETc) compared with $100 \%$ ETc in the 2008 season.

Marketable yield (t.ha $\mathrm{h}^{-1}$ ) tended to increase using high PD compared with the standard PD by $7 \%(P=0.061)$ in 2008 and by $14 \%(P=0.001)$ in 2009 . Deficit irrigation
Table 4. Bulbing ratio onion (cv. TG 1015) as affected by planting density and irrigation rate.

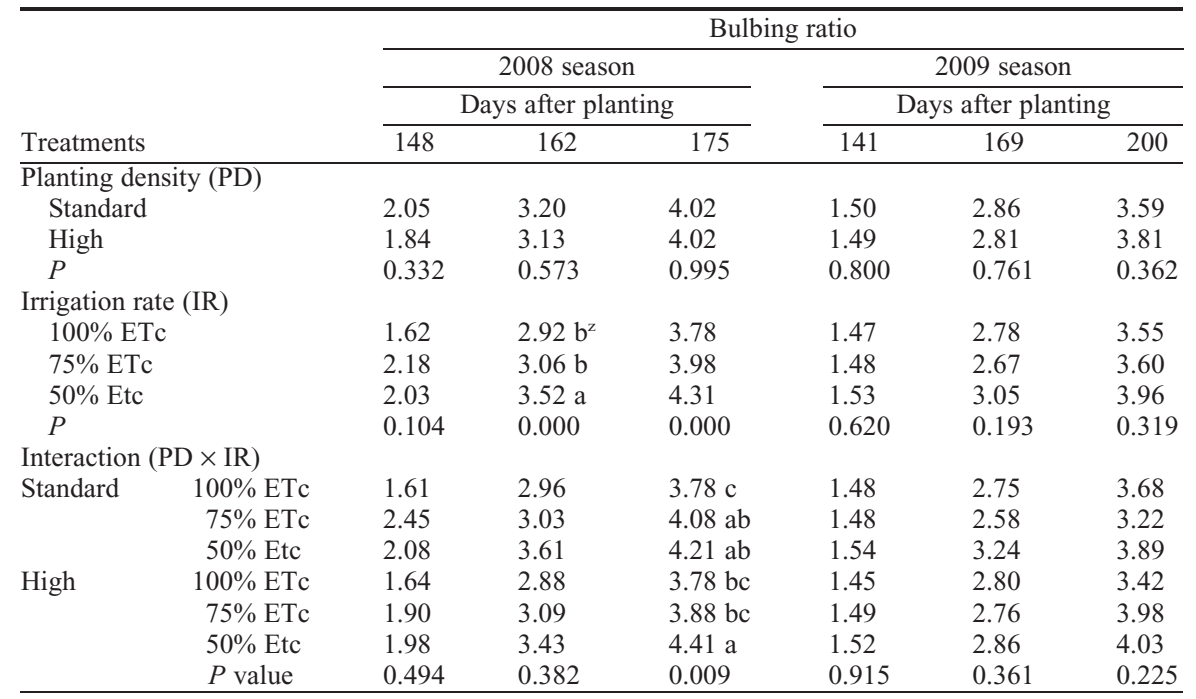

${ }^{\mathrm{z}}$ Means in a column followed by the same letter are not significantly different at $P \leq 0.05$ according to the Tukey's Studentized range test.

$\mathrm{ETc}=$ evapotranspiration

Table 5. Leaf chlorophyll index (SPAD values) of onion (cv. TG 1015) as affected by planting density and irrigation rate.

\begin{tabular}{|c|c|c|c|c|c|c|}
\hline \multirow[b]{4}{*}{ Treatments } & \multicolumn{6}{|c|}{ Leaf chlorophyll index (SPAD values) } \\
\hline & \multicolumn{3}{|c|}{2008 season } & \multicolumn{3}{|c|}{2009 season } \\
\hline & \multicolumn{3}{|c|}{ Days after planting } & \multicolumn{3}{|c|}{ Days after planting } \\
\hline & 147 & 161 & 175 & 141 & 169 & 200 \\
\hline \multicolumn{7}{|l|}{ Planting density } \\
\hline Standard & 56.3 & 58.8 & 59.2 & 58.6 & 56.4 & 40.7 \\
\hline High & 55.2 & 57.9 & 59.2 & 57.0 & 58.9 & 43.0 \\
\hline \multicolumn{7}{|l|}{ Irrigation rate } \\
\hline $100 \%$ ETc & $53.0 \mathrm{c}^{\mathrm{z}}$ & $56.3 \mathrm{c}$ & $62.0 \mathrm{a}$ & 57.0 & 58.0 & 42.6 \\
\hline $75 \%$ ETc & $55.4 \mathrm{~b}$ & $57.7 \mathrm{~b}$ & $58.8 \mathrm{~b}$ & 57.2 & 56.7 & 40.8 \\
\hline $50 \%$ ETc & $58.8 \mathrm{a}$ & $61.0 \mathrm{a}$ & $56.8 \mathrm{~b}$ & 59.3 & 58.1 & 42.3 \\
\hline ANOVA & & & & & & \\
\hline Planting density & 0.021 & 0.092 & 0.972 & 0.462 & 0.232 & 0.220 \\
\hline Irrigation rate & 0.000 & 0.000 & 0.002 & 0.398 & 0.758 & 0.658 \\
\hline Interaction & 0.794 & 0.805 & 0.919 & 0.444 & 0.402 & 0.391 \\
\hline
\end{tabular}

${ }^{\mathrm{z}}$ Means in a column followed by the same letter are not significantly different at $P \leq 0.05$ according to the Tukey's Studentized range test.

$\mathrm{ETc}=$ evapotranspiration; ANOVA $=$ analysis of variance.

Table 6. Leaf fresh weight of onion (cv. TG 1015) as affected by planting density and irrigation rate.

\begin{tabular}{|c|c|c|c|c|c|c|}
\hline \multirow[b]{4}{*}{ Treatments } & \multicolumn{6}{|c|}{ Leaf fresh wt ( $\mathrm{g} / \mathrm{plant})$} \\
\hline & \multicolumn{3}{|c|}{2008 season } & \multicolumn{3}{|c|}{2009 season } \\
\hline & \multicolumn{3}{|c|}{ Days after planting } & \multicolumn{3}{|c|}{ Days after planting } \\
\hline & 148 & 162 & 175 & 141 & 169 & 200 \\
\hline \multicolumn{7}{|l|}{ Planting density } \\
\hline Standard & 88 & 147 & 139 & 88 & 177 & 64 \\
\hline High & 83 & 136 & 117 & 79 & 178 & 60 \\
\hline \multicolumn{7}{|l|}{ Irrigation rate } \\
\hline $100 \%$ ETc & $87 a b^{z}$ & $173 \mathrm{a}$ & $163 \mathrm{a}$ & $94 \mathrm{a}$ & $201 \mathrm{a}$ & $76 \mathrm{a}$ \\
\hline $75 \%$ ETc & 93 a & $151 \mathrm{~b}$ & $134 \mathrm{~b}$ & $78 \mathrm{~b}$ & $186 \mathrm{ab}$ & $63 \mathrm{a}$ \\
\hline $50 \% \mathrm{ETc}$ & $77 \mathrm{~b}$ & $101 \mathrm{c}$ & $86 \mathrm{c}$ & $79 \mathrm{~b}$ & $147 \mathrm{~b}$ & $47 \mathrm{~b}$ \\
\hline ANOVA & \multicolumn{6}{|c|}{$P$} \\
\hline Planting density & 0.532 & 0.192 & 0.087 & 0.098 & 0.974 & 0.621 \\
\hline Irrigation rate & 0.045 & 0.000 & 0.000 & 0.039 & 0.032 & 0.003 \\
\hline Interaction & 0.177 & 0.095 & 0.072 & 0.510 & 0.897 & 0.322 \\
\hline
\end{tabular}

${ }^{\mathrm{z}}$ Means in a column followed by the same letter are not significantly different at $P \leq 0.05$ according to the Tukey's Studentized range test.

$\mathrm{ETc}=$ evapotranspiration; ANOVA $=$ analysis of variance. 
Table 7. Bulb fresh weight of onion (cv. TG 1015) as affected by planting density and irrigation rate.

\begin{tabular}{|c|c|c|c|c|c|c|}
\hline \multirow[b]{4}{*}{ Treatments } & \multicolumn{6}{|c|}{ Bulb fresh wt (g/plant) } \\
\hline & \multicolumn{3}{|c|}{2008 season } & \multicolumn{3}{|c|}{2009 season } \\
\hline & \multicolumn{3}{|c|}{ Days after planting } & \multicolumn{3}{|c|}{ Days after planting } \\
\hline & 148 & 162 & 175 & 141 & 169 & 200 \\
\hline \multicolumn{7}{|l|}{ Planting density } \\
\hline Standard & 19 & 129 & 260 & 13 & 121 & 282 \\
\hline High & 17 & 123 & 229 & 11 & 117 & 266 \\
\hline \multicolumn{7}{|l|}{ Irrigation rate } \\
\hline $100 \%$ ETc & $14 \mathrm{~b}^{\mathrm{z}}$ & 129 & $271 \mathrm{a}$ & 12 & 125 & 284 \\
\hline $75 \%$ ETc & $20 \mathrm{a}$ & 126 & $244 \mathrm{~b}$ & 11 & 117 & 279 \\
\hline $50 \%$ ETc & $20 \mathrm{a}$ & 122 & $219 \mathrm{c}$ & 13 & 116 & 259 \\
\hline ANOVA & \multicolumn{6}{|c|}{$P$} \\
\hline Planting density & 0.242 & 0.392 & 0.000 & 0.092 & 0.608 & 0.365 \\
\hline Irrigation rate & 0.001 & 0.482 & 0.000 & 0.122 & 0.659 & 0.072 \\
\hline Interaction & 0.284 & 0.875 & 0.134 & 0.698 & 0.655 & 0.428 \\
\hline
\end{tabular}

${ }^{2}$ Means in a column followed by the same letter are not significantly different at $P \leq 0.05$ according to the

Tukey's Studentized range test.

$\mathrm{ETc}=$ evapotranspiration; ANOVA $=$ analysis of variance.

Table 8. Marketable yield component of onion (cv. TG 1015) as affected by planting density and irrigation rate.

\begin{tabular}{|c|c|c|c|c|c|c|c|c|}
\hline \multirow[b]{3}{*}{ Treatments } & \multicolumn{8}{|c|}{ Marketable yield } \\
\hline & \multicolumn{4}{|c|}{2008 season } & \multicolumn{4}{|c|}{2009 season } \\
\hline & Bulbs/ha & $\mathrm{g} / \mathrm{bulb}$ & $\mathrm{t} \cdot \mathrm{ha}^{-1}$ & $\begin{array}{l}\text { Percent } \\
(w t / w t)^{z}\end{array}$ & Bulbs/ha & g/bulb & t.ha ${ }^{-1}$ & $\begin{array}{l}\text { Percent } \\
(w t / w t)\end{array}$ \\
\hline \multicolumn{9}{|l|}{ Planting density } \\
\hline Standard & 242,829 & 276 & 66.8 & 99.2 & 224,425 & 232 & 51.9 & 98.8 \\
\hline High & 294,681 & 244 & 71.8 & 99.5 & 298,336 & 201 & 59.2 & 98.9 \\
\hline \multicolumn{9}{|l|}{ Irrigation rate } \\
\hline $100 \%$ ETc & 270,102 & $295 \mathrm{a}^{\mathrm{y}}$ & $78.5 \mathrm{a}$ & 99.6 & 287,931 & 221 & $62.2 \mathrm{a}$ & 99.6 \\
\hline $75 \%$ ETc & 279,193 & $262 \mathrm{~b}$ & $72.4 \mathrm{~b}$ & 99.1 & 251,065 & 219 & $53.9 \mathrm{~b}$ & 99.2 \\
\hline $50 \%$ ETc & 256,971 & $223 \mathrm{c}$ & $56.9 \mathrm{c}$ & 99.3 & 245,145 & 209 & $50.5 \mathrm{~b}$ & 97.8 \\
\hline ANOVA & \multicolumn{8}{|c|}{$P$} \\
\hline Planting density & 0.015 & 0.002 & 0.061 & 0.419 & 0.007 & 0.020 & 0.001 & 0.886 \\
\hline Irrigation rate & 0.160 & 0.000 & 0.000 & 0.563 & 0.228 & 0.612 & 0.000 & 0.154 \\
\hline Interaction & 0.544 & 0.452 & 0.359 & 0.382 & 0.956 & 0.916 & 0.664 & 0.704 \\
\hline
\end{tabular}

${ }^{2}$ Percent of total yield on a fresh weight basis.

${ }^{y}$ Means in a column followed by the same letter are not significantly different at $P \leq 0.05$ according to the

Tukey's Studentized range test.

$\mathrm{ETc}=$ evapotranspiration; ANOVA $=$ analysis of variance. rates significantly impacted marketable yield. The yield reductions by $50 \%$ ETc compared with $100 \%$ ETc were $28 \%$ and $19 \%$ for 2008 and 2009 , respectively. The yield reductions by $75 \%$ ETc compared with $100 \%$ ETc were $8 \%$ and $13 \%$ for 2008 and 2009 , respectively. The percentage of marketable yield was very high and was unaffected by PD or irrigation treatment (Table 8).

Bulb size distribution. There were significant effects of both PD and irrigation rates on medium and jumbo sizes during the 2008 season (Table 9). Higher percentages of medium bulbs were obtained with the high PD (average 36.1\%) and with the 50\% ETc irrigation rate (average $42.5 \%$ ), whereas the largest percentage of jumbo bulbs was obtained with the standard PD (average 19.2\%) and with $100 \%$ ETc irrigation rate $(22.3 \%)$. In this season, there were significant PD $\times$ irrigation rate interactions $(P \leq 0.05)$ for small, large, and colossal bulbs. A higher percentage (although numerically low) of small bulbs was present when plants were irrigated with the $50 \%$ ETc rate $(2.3 \%$ in both PDs). For the large size category, more bulbs were obtained with the standard PD and 50\% ETc $(44.4 \%)$ or with the high PD irrigated with $100 \%(42.8 \%)$ or $75 \%$ ETc $(43.4 \%)$. For the colossal bulb category, the highest percentage was obtained for the standard PD and $100 \%$ ETc followed by the standard PD and $75 \%$ ETc (Table 9).

In the 2009 season, PD was the only factor impacting bulb sizes for the medium and jumbo categories at $P \leq 0.05$ (Table 9). The high PD led to a higher percentage of medium bulbs (average 46.3\%) and lower percentage of jumbo-sized bulbs (6.7\%). Conversely, the standard PD led to a lower percentage of medium bulbs (average 31.2\%) and more jumbo-sized bulbs (14.3\%).

Soluble solids, pyruvic acid, and quercetin. Although there was a decreasing trend in soluble solids content and an increase in

Table 9. Bulb size distribution of onion (cv. TG 1015) as affected by planting density and irrigation rate.

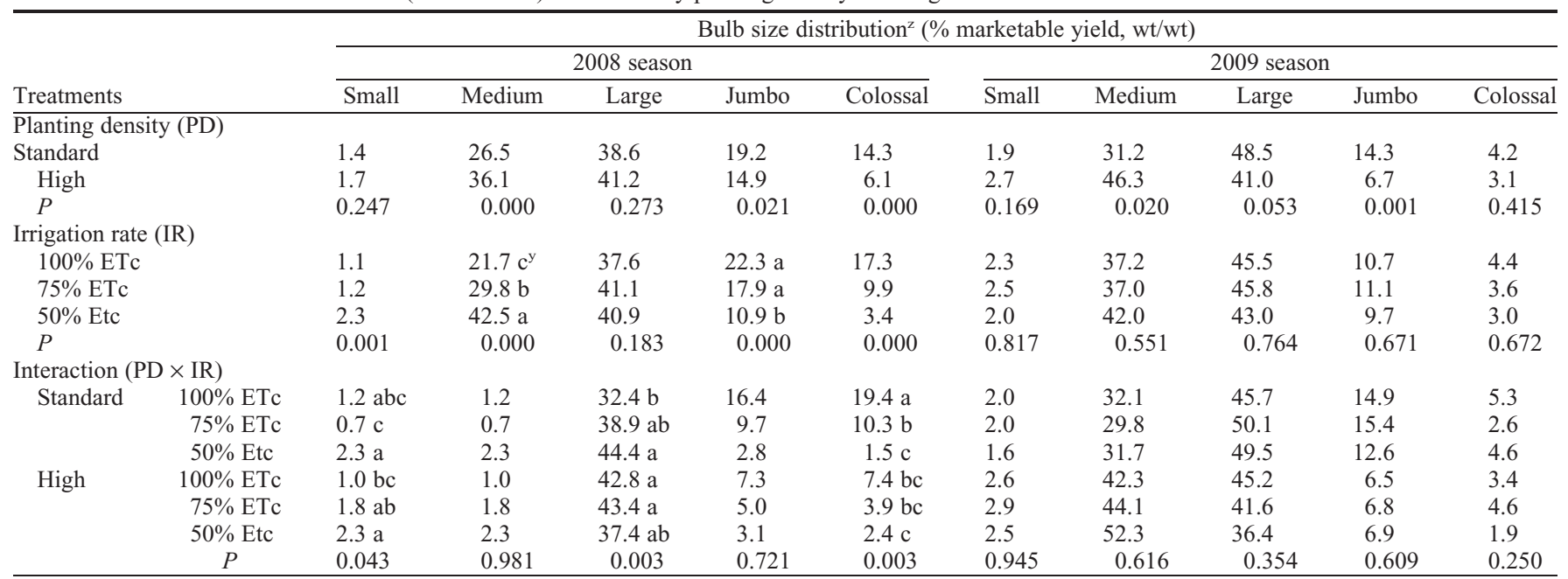

${ }^{2}$ Onion bulbs were categorized as small (less than $\left.5.7 \mathrm{~cm}\right)$, medium $(5.7-7.6 \mathrm{~cm})$, large $(7.6-9.5 \mathrm{~cm})$, jumbo $(9.5-10.5 \mathrm{~cm})$, and colossal $(\mathrm{greater}$ than $10.5 \mathrm{~cm})$ based on bulb diameter.

y Means in a column followed by the same letter are not significantly different at $P \leq 0.05$ according to the Tukey's Studentized range test.

$\mathrm{ETc}=$ evapotranspiration 
Table 10. Soluble solids content (SSC), pyruvic acid, and quercetin concentrations in large size bulbs (diameter of 7.6-9.5 cm) of onion (cv. TG 1015) as affected by planting density and irrigation rate.

\begin{tabular}{|c|c|c|c|c|c|c|}
\hline \multirow[b]{2}{*}{ Treatments } & \multicolumn{3}{|c|}{2008 season } & \multicolumn{3}{|c|}{2009 season } \\
\hline & SSC (\%) & $\begin{array}{l}\text { Pyruvic acid } \\
\left(\mu \mathrm{mol} \cdot \mathrm{mL}^{-1}\right)\end{array}$ & $\begin{array}{c}\text { Quercetin } \\
\left(\mu \mathrm{g} \cdot \mathrm{g}^{-1} \mathrm{FW}\right)\end{array}$ & SSC (\%) & $\begin{array}{l}\text { Pyruvic acid } \\
\left(\mu \mathrm{mol} \cdot \mathrm{mL}^{-1}\right)\end{array}$ & $\begin{array}{c}\text { Quercetin } \\
\left(\mu \mathrm{g} \cdot \mathrm{g}^{-1} \mathrm{FW}\right)\end{array}$ \\
\hline \multicolumn{7}{|l|}{ Planting density } \\
\hline Standard & 6.28 & 3.73 & 61.7 & 6.99 & 3.96 & 105.2 \\
\hline High & 6.25 & 3.63 & 58.2 & 7.06 & 3.49 & 108.0 \\
\hline \multicolumn{7}{|l|}{ Irrigation rate } \\
\hline $100 \%$ ETc & 6.49 & 3.59 & 53.9 & 7.03 & 3.44 & 100.8 \\
\hline $75 \%$ ETc & 6.26 & 3.85 & 59.7 & 7.15 & 3.69 & 98.7 \\
\hline $50 \%$ ETc & 6.05 & 3.60 & 66.1 & 6.90 & 3.60 & 93.8 \\
\hline ANOVA & \multicolumn{6}{|c|}{$P$} \\
\hline Planting density & 0.843 & 0.731 & 0.625 & 0.580 & 0.997 & 0.264 \\
\hline Irrigation rate & 0.079 & 0.401 & 0.382 & 0.244 & 0.129 & 0.900 \\
\hline Interaction & 0.820 & 0.525 & 0.326 & 0.589 & 0.146 & 0.894 \\
\hline
\end{tabular}

$\mathrm{FW}=$ fresh weight; ETc $=$ evapotranspiration; ANOVA $=$ analysis of variance.

pyruvic acid in response to deficit irrigation, neither PD nor irrigation rate nor their interactions affected total soluble solid content, pyruvic acid, and quercetin concentration (Table 10).

\section{Discussion}

Planting density did not affect the aerial plant development (leaf number, plant height, leaf FW), which was in accordance with Brewster and Salter (1980), who reported that plant height did not differ significantly among three PD $(430,000,860,000$ and $1,290,000$ plants/ha). A PD study by Kanton et al. (2002) showed no differences on the number of leaves per plant, but plant height and bulb size decreased as PD increased from 370,400 to $1,562,500$ plants/ha. A study conducted in Brazil by Cecílio Filho et al. (2009) showed that increasing PDs from 600,000 to $1,080,000$ plants/ha decreased dry mass of the aerial part and bulbs.

Greater yields per hectare with lower weight per bulb, as demonstrated in this study for the high PD in a short-day onion (Table 8), were also shown for other onion types. In long-day onions evaluated in Oregon, Shock et al. (2004) showed a positive yield response with increasing plant population in the range of 185,000-370,000 plants/ha. In Italian onion cultivars, Dellacecca and Lovato (2000) obtained a $50 \%$ increase in yield when increasing PD from 266,000 to 800,000 plants/ha. Similarly, Brewster and Salter (1980) also obtained a $43 \%$ yield increase when using $1,290,000$ plants/ha compared with 430,000 plants/ha.

Irrigation rates had a greater impact than PD on shoot growth, bulb size, and marketable yields. Kumar et al. (2007b) reported a progressive increase in onion plant biomass (dry weight basis) with increasing irrigation levels from $60 \%$ to $120 \%$ ETc. In their study, irrigation was applied with a microsprinkler system based on cumulative pan evaporation. In Ethiopia, Bekele and Tilahum (2007) also reported yield reductions of $15 \%$ and $45 \%$ with deficit irrigation at $75 \%$ and $50 \%$ ETc. In a 2-year study, Ells et al. (1993) compared three furrow irrigation rates $(75 \%, 100 \%$, and
$200 \%$ ETc); onion yields were reduced only in 1 year by $12 \%$ with $75 \%$ ETc compared with $100 \%$ ETc, but no difference was found between the $100 \%$ and $200 \%$ ETc rates. High average bulb size at $100 \%$ ETc irrigation rate is in agreement with the findings of Enciso et al. (2009) and Kumar et al. (2007a, 2007b).

Onion size is also influenced by irrigation method and the timing of imposing water stress. Halvorson et al. (2008) obtained a greater percentage of colossal and jumbo-sized bulbs under drip compared with furrow irrigation. Studies by Shock et al. $(1998,2000)$ comparing different soil water potential thresholds for furrow and subsurface drip irrigation reported an increase in marketable yield and percentage of large-sized bulbs with high soil water potentials (range, -10 to $-21 \mathrm{kPa}$ ). A follow-up study by Shock et al. (2007) analyzing the effect of water stress in different growth stages showed yield reduction of larger bulb sizes (combined jumbo, colossal, and super colossal) when the stress was applied at the eight-leaf stage as compared with nonstressed plants. Traditionally, total bulb yield has been used as a good indicator for potential income, but this is not always translated into the greatest profit. Typically, growers receive higher prices for large and jumbo-sized bulbs; therefore, they are interested in increasing marketable yield as well as yield of bigger size classes (Boyhan et al., 2005).

Onion pungency is known to differ with cultivar, stage of maturity, type of soil, soil moisture, and other growing conditions (Kalra et al., 1995; Saghir et al., 1965). In our study, no significant effect of PD and irrigation rates was recorded on pungency. Similarly, total soluble solids and quercetin content were unaffected by both treatments. This is consistent with findings from previous studies (Enciso et al., 2009; Jiménez et al., 2010; Leskovar et al., 2004). In contrast, Kumar et al. (2007a) found slightly higher total soluble solids at 1.00 pan evaporation replacement (Ep) as compared with 0.6 or $1.2 \mathrm{Ep}$. However, their study used a red-colored cultivar, transplants, and a microsprinkler irrigation system.

In conclusion, this 2-year study demonstrated that both irrigation rate and PD had an impact on marketable yield but not on flavor components and quercetin content of shortday onion. On average, total bulb yields were increased $(\approx 14 \%)$, whereas average bulb size decreased in response to increased PD. The decline in onion yield by deficit irrigation applied by subsurface drip at $75 \%$ ETc and using growth stage-specific crop coefficients was modest, $8 \%$ compared with $23 \%$ at $50 \%$ ETc. However, deficit irrigation would result in losses of high-value bulbs. As drought episodes continue to impose significant threats to agricultural production, especially in semiarid regions, we expect some onion growers to adopt water-conserving practices $(75 \%$ ETc rate). Our findings are useful for refining short-day onion crop management practices aimed at optimizing yields for water-restricted areas.

\section{Literature Cited}

Abayomi, L.A., L.A. Terry, S.F. White, and P.J. Warner. 2006. Development of a disposable pyruvate biosensor to determine pungency in onions (Allium cepa L.). Biosens. Bioelectron. 21:2176-2179.

Bekele, S. and K. Tilahum. 2007. Regulated deficit irrigation scheduling of onion in a semiarid region of Ethiopia. Agr. Water Mgt. 89:148152.

Bessembinder, J.J.E., P.A. Leffelaar, A.S. Dhindmal, and T.C. Ponsioen. 2005. Which crop and which drop, and the scope for improvement of water productivity. Agr. Water Mgt. 73:113130 .

Boyhan, G.E., A.C. Purvis, W.M. Randle, R.L. Torrance, M. Jeffernson Cook, IV, G. Hardisson, R.H. Backley, H. Paradise, R.C. Hill, and J.T. Panlk. 2005. Harvest and postharvest quality of short-day onions in variety trials in Georgia, 2000-03. HortTechnology 15:694-706.

Brewster, J.L. 2008. The classification, origins, distribution and economic importance of the major vegetable crops in onions and other vegetable alliums. 2nd Ed. CABI, Wallingford, UK.

Brewster, J.L. and P.J. Salter. 1980. The effect of plant spacing on the yield and bolting of two cultivars of overwintered bulb onions. J. Hort. Sci. 5:97-102.

Caliskan, M.E., N. Kusman, and S. Caliskan. 2009. Effects of plant density and yield components of true potato seed (TPS) hybrids in early and main crop potato production systems. Field Crops Res. 114:223-232.

Caridi, D., V.C. Trenerry, S. Rochfort, S. Duong, D. Laugher, and R. Jones. 2007. Profiling and quantifying quercetin glucosides in onion (Allium cepa L.) varieties using capillary zone electrophoresis and high performance liquid chromatography. Food Chem. 105:691-699.

Cecílio Filho, A.B., A. May, D.R.Q. Porto, and J.C. Barbosa. 2009. Crescimento da cebola em função de doses de nitrógeno, potasio e da população de plantas em semeadura directa. Hort. Brasileira 27:49-54.

Chalmers, D.J., P.D. Mitchel, and L. van Heek. 1981. Control of peach tree growth and productivity by regulated water supply, tree density and summer pruning. J. Amer. Soc. Hort. Sci. 106:307-312.

Dellacecca, V. and A.F.S. Lovato. 2000. Effects of different plant densities and planting systems on onion (Allium cepa L.) bulb quality and yield. Acta Hort. 533:197-203.

Dhumal, K., S. Datir, and R. Pandey. 2007. Assessment of bulb pungency level in different Indian 
cultivars of onion (Allium cepa L.). Food Chem. 100:1328-1330.

Ells, J.E., A.E. McSay, P.N. Soltanpour, F.C. Schweissing, M.E. Bartolo, and E.G. Kruse. 1993. Onion irrigation and nitrogen leaching in the Arkansas Valley of Colorado 1990-1991. HortTechnology 3:184-187.

Enciso, J., B. Wiedenfeld, J. Jifon, and S. Nelson. 2009. Onion yield and quality response to two irrigation scheduling strategies. Sci. Hort. 120: 301-305.

FAO. 2002. Deficit irrigation practices. Water reports, 22. FAO, Rome, Italy.

FAO. 2010. Food and agricultural commodities production. 11 Oct. 2010. <faostat.fao.org/site/ 339/default.aspx>.

Griffiths, G., L. Trueman, T. Crowther, B. Tomas, and B. Smith. 2002. Onions- A global benefit to health. Phytother. Res. 16:603-615.

Halvorson, A.D., M.E. Bartolo, C.A. Reule, and A. Berrada. 2008. Nitrogen effects on onion yield under drip and furrow irrigation. Agron. J. 100: 1062-1069.

Jiménez, M., J.A. De Juan, J.M. Tarjuelo, and J.F. Ortega. 2010. Effect of irrigation uniformity on evapotranspiration and onion yield. J. Agr. Sci. 148:139-157.

Kalra, A., D.R. Sood, and U.C. Pandey. 1995. Studies on growth, pungency and flavour characteristics of different varieties of onions during bulb development. J. Food Sci. Technol. 32:189-192.

Kanton, R.A.L., L. Abbey, R.G. Hilla, M.A. Tabil, and N.D. Jan. 2002. Density affects plant development and yield of bulb onion (Allium сера L.) in Northen Ghana. J. Veg. Crop Production 8:5-25.

Kopsell, D.E. and W.M. Randle. 1997. Onion cultivars differ in pungency and bulb quality changes during storage. HortScience 32:1260-1263.

Kumar, S., M. Imtiyaz, and A. Kumar. 2007a. Effect of differential soil moisture and nutrient regimes on postharvest attributes of onion (Allium cepa L.). Sci. Hort. 112:121-129.

Kumar, S., M. Imtiyaz, A. Kumar, and R. Singh. 2007b. Response of onion (Allium cepa L.) to different levels of irrigation water. Agr. Water Mgt. 89:161-166.

Lee, Y., L.R. Howard, and B. Villalón. 1995. Flavonoids and antioxidant activity of fresh pepper (Capsicum annuum) cultivars. J. Food Sci. 60:473-476.

Leskovar, D.I., K. Kolenda, K.S. Yoo, and L.M Pike. 2004. Containerized transplants and subsurface drip improved yield and quality of short-day onions. Acta Hort. 631:155-160

Mogren, L., M.E. Olsson, and U.E. Gertsson. 2007. Effects of cultivar, lifting time and nitrogen fertiliser level on quercetin content in onion (Allium cepa L.) at lifting. J. Sci. Food Agr. 87:470-476.

Patel, N. and T.B.S. Rajput. 2008. Dynamics and modelling of soil water under subsurface drip irrigated onion. Agr. Water Mgt. 95:1335-1349.

Patel, N. and T.B.S. Rajput. 2009. Effect of subsurface drip irrigation on onion yield. Irrig. Sci. 27:97-108.

Patil, B.S., L.M. Pike, and K.S. Yoo. 1995. Variation in the quercetin content in different colored onions (Allium cepa L.). J. Amer. Soc. Hort. Sci. 120:909-913.

Piccinni, G., J. Ko, T. Marek, and D.I. Leskovar. 2009. Crop coefficients specific to multiple phenological stages for evapotranspirationbased irrigation management of onion and spinach. HortScience 44:421-425.

Saghir, A.R., L.K. Mann, and M. Yamaguchi. 1965. Composition of volatiles in allium as related to habitat, stage of maturity and plant part. Plant Physiol. 40:681-685.

SAS Institute Inc. 1993. SAS/STAT ${ }^{\circledR}$ user's guide, Version 6. 2nd Ed. Cary, NC.

Shock, C.C., E.B. Feibert, and L.D. Saunders. 1998. Onion yield and quality affected by soil water potential as irrigation threshold. HortScience 33:1188-1191.

Shock, C.C., E.B. Feibert, and L.D. Saunders. 2000. Irrigation criteria for drip-irrigated onions. HortScience 35:63-66.

Shock, C.C., E.B. Feibert, and L.D. Saunders. 2004. Plant population and nitrogen fertilization for subsurface drip-irrigated onion. HortScience 39:1722-1727.

Shock, C.C., E.B. Feibert, and L.D. Saunders. 2007. Short-duration water stress decreases onion single centers without causing translucent scale. HortScience 42:1450-1455.

Whitaker, J. 1976. Development of flavour, odor and pungency in onion and garlic. Adv. Food Res. 22:73-133.

Yoo, K.S. and L.M. Pike. 1999. Development of an automated system for pyruvic acid analysis in onion breeding. Sci. Hort. 82:193-201. 